\title{
Interleukin-4 receptor targeted immunotherapy of human bladder cancer in animal models
}

\author{
Bharat H Joshi ${ }^{*}$, Akiko Suzuki ${ }^{2}$, Pamela Leland ${ }^{2}$, Samir Lababidi ${ }^{3}$, Frederick Varrichio ${ }^{4}$, Robert Kreitman ${ }^{5}$, Raj K Puri ${ }^{1}$ \\ From Society for Immunotherapy of Cancer 29th Annual Meeting \\ National Harbor, MD, USA. 6-9 November 2014
}

Previously, we have demonstrated that Interleukin-4 (IL-4) receptor alpha (IL-4R $\alpha$ ) is overexpressed in bladder cancer biopsy specimens and its expression level correlates with the grade and stage of disease. Based on these observations, it is proposed that IL-4R $\alpha$ is a prognostic biomarker for bladder cancer. To target IL-4R $\alpha$, we have developed a recombinant chimeric fusion immunotoxin, which consists of circularly permuted IL- 4 and truncated Pseudomonas exotoxin (IL-4-PE) [1]. Here we demonstrate that IL-4-PE is highly cytotoxic to eight bladder cancer cell lines in vitro. The cytotoxicity by IL-4-PE was mediated in a concentration dependent manner and this cytotoxicity was receptor specific as excess IL-4 inhibited cytotoxicity mediated by IL-4-PE. IL-4-PE immunotoxin also killed bladder cancer colonies in a concentration dependent manner in a clonogenic assay. We developed three subcutaneous tumor models in athymic nude mice using three different bladder cancer cell lines (UM-UC-3, SW780 and 5637), which are sensitive to IL-4-PE at a variable degree. These mice were treated with $50 \mu \mathrm{g} / \mathrm{kg}, 100 \mu \mathrm{g} / \mathrm{kg}$ of IL-4PE immunotoxin or vehicle-control intratumorally and monitored for tumor growth and survival. IL-4-PE effectively caused regression of tumors by $70 \%$ in all three tumor models compared to vehicle control mice. Responding animals showed complete regression of tumors in $58 \%$ of mice at the highest dose in UM-UC-3 tumor model and 54\% in SW780 tumor model. Overall, all responding animals showed $>8$ week longer survival compared to control mice. IL-4-PE immunotoxin at both doses did not show any visible toxicity when administrated intratumorally. Similar safety profile has been observed in the clinic when IL-4-PE was administered intratumorally in glioma trial [2]. Taken together our results demonstrate that IL-4R $\alpha$ in bladder cancer is a prognostic biomarker

'Division of Cellular and Gene Therapies, Center for Biologics Evaluation and Research, FDA, Bethesda, USA

Full list of author information is available at the end of the article and in addition it provides an excellent target for immunotherapy. Additional studies are ongoing to target IL-4R $\alpha$ with other immunotherapeutic approaches such as cancer vaccines and adoptive cell transfer immunotherapy.

\section{Authors' details}

'Division of Cellular and Gene Therapies, Center for Biologics Evaluation and Research, FDA, Bethesda, USA. ${ }^{2}$ CBER, FDA, USA. ${ }^{3}$ CBER, FDA, Silver Spring, USA. ${ }^{4} \mathrm{CBER}$, FDA, Wakefield, USA. ${ }^{5} \mathrm{NCl}, \mathrm{NIH}$, USA.

Published: 6 November 2014

\section{References}

1. Puri R: Development of a Recombinant Interleukin-4-Pseudomonas exotoxin for Therapy of Glioblastoma. Toxicologic Pathol 1999, 27:53-57.

2. Weber F, Asher A, Bucholz R, Berger M, Prados M, Chang S, Bruce J, Hall W, Rainov NG, Westphal M, Warnick RE, Rand RW, Floeth F, Rommel F, Pan H, Hingorani VN, Puri RK: Safety, tolerability, and tumor response of IL4Pseudomonas exotoxin (NBI-3001) in patients with recurrent malignant glioma. J Neuro-Oncol 64:125-137.

\section{doi:10.1186/2051-1426-2-S3-P184}

Cite this article as: Joshi et al.: Interleukin-4 receptor targeted

immunotherapy of human bladder cancer in animal models. Journal for ImmunoTherapy of Cancer 2014 2(Suppl 3):P184.

Submit your next manuscript to BioMed Central and take full advantage of:

- Convenient online submission

- Thorough peer review

- No space constraints or color figure charges

- Immediate publication on acceptance

- Inclusion in PubMed, CAS, Scopus and Google Scholar

- Research which is freely available for redistribution 